\title{
Isolation and characterization of halophilic strains from beef jerky
}

\author{
Isolamento e caracterização de cepas halófilas a partir de charque \\ Aislamiento y caracterización de cepas halófilas de charque
}

Received: 01/31/2022 | Reviewed: 02/08/2022 | Accept: 02/13/2022 | Published: 02/18/2022

\author{
Aloisio Freitas Chagas Junior \\ ORCID: https://orcid.org/0000-0002-7489-8701 \\ Universidade Federal do Tocantins, Brasil \\ E-mail: chagasjraf@uft.edu.br \\ Eduardo Henrique Santos Guedes \\ ORCID: https://orcid.org/0000-0003-3189-9576 \\ Universidade Federal do Tocantins, Brasil \\ E-mail: edu3-d@hotmail.com \\ Camila Mariane da Silva Soares \\ ORCID: https://orcid.org/0000-0002-6194-5126 \\ Universidade Federal de Lavras, Brasil \\ E-mail: cammisoares06@gmail.com \\ Mirella Gonçalves Cunha \\ ORCID: https://orcid.org/0000-0002-6366-5347 \\ Universidade Estadual de Goiás, Brasil \\ E-mail: mirella_cunha@hotmail.com \\ André Leonardo dos Santos \\ ORCID: https://orcid.org/0000-0001-7795-2825 \\ Universidade Federal Rural do Rio de Janeiro, Brasil \\ E-mail: ibiapinaandreia@gmail.com \\ Aynaran Oliveira Aguiar \\ ORCID: https://orcid.org/0000-0002-3596-0699 \\ Universidade Federal do Tocantins, Brasil \\ E-mail: aynaranaguiar@gmail.com \\ Albert Lennon Lima Martins \\ ORCID: https://orcid.org/0000-0003-2683-2035 \\ Universidade Federal do Tocantins, Brasil \\ E-mail: eng.albertlennon@gmail.com
}

\begin{abstract}
Beef jerky is a typically Brazilian food product that consists of adding salt (sodium chloride, $\mathrm{NaCl}$ ) to bovine meat. Salt is used as main preservative when preparing jerked meat, however, certain species of microorganisms, known as halophiles, optimally develop in the presence of high salt concentrations, thus salty food may contain halophiles and cause undesirable alterations in the products. In this context, this study aims to isolate, characterize, and assess the growth parameters of halophilic strains isolated from beef jerky. Two halophilic strains were isolated: C11 strain, with cocci-shaped morphological features from white cream color, and V22 strain, with red pleomorphism. Both the lineages were gran-negative, catalase, and oxidase positive, with optimum growth time after 15 incubation days at 37 ${ }^{\circ} \mathrm{C}$. The strains were neutrophilic, growing only at $\mathrm{pH} 7.0$ and subjected to a $2 \times 3$ factorial experimental design to assess and optimize the growth of strains at different concentrations of $\mathrm{NaCl}, \mathrm{MgCl}_{2}$, and yeast extract. We found that for both the optimal growth conditions, the studied variables ranged from 25 to $35 \mathrm{~g} \mathrm{~L}^{-1}$ of $\mathrm{MgCl}_{2}, 5 \mathrm{~g} \mathrm{~L}^{-1}$ of yeast extract, but for $\mathrm{NaCl}$, the $\mathrm{C} 11$ strain did not grow in medium containing $300 \mathrm{~g} \mathrm{~L}^{-1}$ (optimally at 200), while the V22 showed no growth in medium containing $100 \mathrm{~g} \mathrm{~L}^{-1}$ (optimally at 300). Therefore, the features of the isolates suggest that they belong to the Halobacteriaceae family.
\end{abstract}

Keywords: Bacteria; Archaea; Physiological features.

\section{Resumo}

Charque é um produto alimentício tipicamente brasileiro que consiste na adição de sal (cloreto de sódio - $\mathrm{NaCl}$ ) em carne bovina. O sal é utilizado como conservante principal no preparo das carnes secas, entretanto certas espécies de microrganismos, conhecidos como halófilos, desenvolvem-se de maneira ideal na presença de altas concentrações de sal e consequentemente alimentos salgados podem conter halófilos e ocasionar alterações indesejáveis nesses produtos. Neste contexto esse estudo teve como objetivo isolar, caracterizar e avaliar os parâmetros no crescimento de cepas halófilas isoladas a partir de charque. Duas cepas halofílicas foram isoladas, sendo a cepa C11 com características morfológicas de cocos de colônia creme branca, enquanto a cepa V22 apresentou pleomorfica pigmentada de vermelha. Ambas as linhagens foram gran-negativas, catalase e oxidase positivas, com tempo ideal de crescimento após 15 dias de incubação a $37^{\circ} \mathrm{C}$. As cepas eram neutrófilas, crescendo apenas em pH 7,0 e após um 
planejamento experimental fatorial 2x3, para avaliar e otimizar o crescimento das cepas em diferentes concentrações de $\mathrm{NaCl}, \mathrm{MgCl}_{2}$ e extrato de levedura. Verificamos que para ambas as condições ótimas de crescimento, as variáveis estudadas variaram de 25 a $35 \mathrm{~g} \mathrm{~L}^{-1}$ de $\mathrm{MgCl}_{2}, 5 \mathrm{~g} \mathrm{~L}^{-1}$ de extrato de levedura, mas para $\mathrm{NaCl}$, a cepa $\mathrm{C} 11$ não cresceu em meio contendo $300 \mathrm{~g} \mathrm{~L}^{-1}$ (otimamente a 200), enquanto o V22 não apresentou crescimento em meio contendo 100 $\mathrm{g} \mathrm{L}^{-1}$ (otimamente a 300). Portanto, as características dos isolados sugerem que eles pertencem à família Halobacteriaceae.

Palavras-chave: Bactérias; Archaea; Características fisiológicas.

\section{Resumen}

El charque es un producto alimenticio típicamente brasileño que consiste en agregar sal (cloruro de sodio - $\mathrm{NaCl}$ ) a la carne bovina. La sal se utiliza como conservante principal en la preparación de carnes secas, sin embargo ciertas especies de microorganismos, conocidos como halófilos, se desarrollan idealmente en presencia de altas concentraciones de sal y consecuentemente los alimentos salados pueden contener halófilos y provocar cambios indeseables en estos productos. En este contexto, este estudio tuvo como objetivo aislar, caracterizar y evaluar los parámetros de crecimiento de cepas halófilas aisladas de charque. Se aislaron dos cepas halófilas, siendo la cepa C11 con características morfológicas de cocos colonia crema blanca, mientras que la cepa V22 presentó pleomorfa pigmentada en rojo. Ambas cepas fueron gram negativas, catalasa y oxidada positivas, con un tiempo de crecimiento ideal a los 15 días de incubación a $37^{\circ} \mathrm{C}$. Las cepas fueron neutrófilos, creciendo solo a pH 7.0 y luego de un diseño experimental factorial $2 \times 3$, para evaluar y optimizar el crecimiento de las cepas en diferentes concentraciones de $\mathrm{NaCl}, \mathrm{MgCl}_{2}$ y extracto de levadura. Encontramos que, para ambas condiciones óptimas de crecimiento, las variables estudiadas oscilaron entre 25 y $35 \mathrm{~g} \mathrm{~L}^{-1}$ de $\mathrm{MgCl} 2,5 \mathrm{~g} \mathrm{~L}^{-1}$ de extracto de levadura, pero para $\mathrm{NaCl}$, la cepa $\mathrm{C} 11$ no creció en un medio que contenía 300 (óptimamente a 200) $\mathrm{g} \mathrm{L}^{-1}$, mientras que V22 no creció en medio que contenía 100 (óptimamente a 300) $\mathrm{g} \mathrm{L}^{-1}$. Por tanto, las características de los aislados sugieren que pertenecen a la familia Halobacteriaceae.

Palabras clave: Bacteria; Archaea; Características fisiológicas.

\section{Introduction}

Beef jerky is a typical Brazilian food product that consists of adding sodium chloride $(\mathrm{NaCl})$ to bovine meat (or other species) subjected to drying processes encompassing the steps of deboning, butchering, wet and dry salting, removal of excess salt, drying, and filling in vacuum packaging (Brazil 2020). It is a product of economic importance in many countries, the salting technique to produce jerked meat has been used for in natura meat preservation since ancient times (Vidal et al., 2019).

Salt is used as main preservative in the preparation of jerked meat based on two different methods: by immersing the meat into wet salting or by forming stacks of meat interleaved by salt layers (dry salting). Both processes can be applied in combination or separately and provide the product with desirable sensorial alterations (Picchi, 2015).

In addition to altering taste, odor, and texture of meat, $\mathrm{NaCl}$ used in the food industry was initially used for preservation to prevent deteriorating microorganisms from proliferating based on the principle of their capacity to reduce activity of water (Inguglia et al., 2017). However, certain species of microorganisms, known as halophiles, require optimum high concentrations of salt to develop (Tortora et al., 2017).

These microorganisms inhabit hypersaline sites all over the globe, such as salt lakes, marine environments, and marine salt pans. As well as the salt derived from these sources is used for salting products of animal origin, like meat, skins, and leather, halophilic microorganisms present in the salt start to develop (Enquahone et al., 2020).

Halophiles may require different salt concentrations and are classified according to their optimum need of concentration, while non-halophilic microorganisms require less than $1 \%(0.2 \mathrm{M})$ of $\mathrm{NaCl}$, halotolerant at $1-3 \%(0.2-0.5 \mathrm{M})$ of $\mathrm{NaCl}$, halophilic 3-15\% (0.5-2.5 M) of $\mathrm{NaCl}$, and extreme halophilic with optimum growth at 15-30\% (2.5-5.2 $\mathrm{M})$ of $\mathrm{NaCl}$. The main organisms reported as having affinity with high salt concentrations are prokaryotes belonging to the bacteria domain, especially archaea (Amoozegar et al., 2017).

Madigan et al., (2016) report that it was only in the mid-nineties that the Archaea domain was first proposed by Woese et al., (1990) as prokaryotic organisms similar to bacteria, but without predominance of lipid membrane, isoprenoid 
glycerol diethers or diglycerol tetraethers, and without the presence of peptidoglycan in the cell wall, thus differing from the Bacteria and Eukarya domains regarding their genetic, molecular, physiological, and structural features.

This domain included an exceptionally interesting and diverse group of prokaryotes whose cell walls do not have peptidoglycan. Studies on these organisms have demonstrated their extraordinary metabolic properties involving uncommon metabolic processes of a fairly particular phylogeny, especially for being the only microorganisms to develop in extreme conditions of temperature, $\mathrm{pH}$, and salinity (Tortora et al., 2017).

The classes of Halobacteria or Haloarchaea are highlighted in the archaea domain for being regarded as two of the largest groups in the domain, with only one order, Halobacterial, and a single family, Halobacteriaceae (Gupta et al., 2015).

As extremophiles, haloarchaea have remarkable and attractive features for their limits of life (by deepening survival mechanisms in extreme and hostile environments) and enlarging the understanding of our planetary biodiversity by providing a larger view of cell functioning, in addition to biotechnological industrial applications for highly stable and active biomolecules under extreme conditions (Quadri et al., 2016).

For inhabiting saline lakes, saline environments, and consequently salty food, haloarchaea may cause undesirable alterations in salted meat products. They appear through reddish or pinkish spots and a strong putrefaction odor in the products (Moschetti et al., 2006). Enquahone et al. (2020) explain that the emergence of reddish spots in meat and salted skins is peculiar to colonies of these organisms since they produce such type of pigmentation. In addition, for being aerobes and mesophiles, their growth becomes accelerated, especially in tropical regions; therefore, obstacles must be imposed to prevent contamination.

Halophilic species may involve some variation especially considering the diversity of environments where these organisms are studied. Thus, the type of halophilic microorganism may differ from one location to another depending on the source of salt used for salting, and it is essential to know the species involved in deterioration to establish control strategies (Caglayan et al., 2015).

Based on the aforementioned information, it is suggested that these microorganisms hold great commercial value both for their deteriorating action and for the production of stable molecules of biotechnological interest, which makes their identification and characterization of major importance for different industrial areas, such as food, pharmaceutical, and effluent treatments. So far, most studies have concentrated on halophilic archaea isolated from soil and salt lakes (Singh and Singh, 2018, Sahli et al., 2020).

In this context, this study aimed to isolate, characterize, and assess the growth parameters of halophilic strains isolated from beef jerky.

\section{Methodology}

\subsection{Sample}

For the isolation of the halophilic strains, we used a sample of beef jerky, salted dried bovine meat in visible contaminated deterioration process, kindly granted by Bello Charque Alimentos Eireli.

\subsection{Isolation and production of halophilic strains}

The strains were isolated according to the methodology proposed by Sahli et al., (2020), with modifications, using the culture enrichment technique along with surface washing technique of the sample.

We used an enriched culture medium (ECM) composed of $5 \mathrm{~g} \mathrm{~L}^{-1}$ peptone, $1 \mathrm{~g} \mathrm{~L}^{-1}$ yeast extract, $200 \mathrm{~g} \mathrm{~L}^{-1} \mathrm{NaCl}, 30 \mathrm{~g}$ $\mathrm{MgCl}_{2} \cdot 6 \mathrm{H}_{2} \mathrm{O}, 30 \mathrm{~g} \mathrm{MgSO}_{4} \cdot 7 \mathrm{H}_{2} \mathrm{O}, 0.5 \mathrm{~g} \mathrm{CaCl}_{2} \cdot 2 \mathrm{H}_{2} \mathrm{O}$, and $7 \mathrm{~g} \mathrm{KCl}$, pH adjusted to 7.2. The solid medium was added with $17 \mathrm{~g}$ $\mathrm{L}^{-1}$ agar. 
All experiments were performed at the temperature of $37^{\circ} \mathrm{C}$ based on the many reports in the literature for optimum growth temperature for halophilic archaea around 37 and $42{ }^{\circ} \mathrm{C}$, as in Schneegurt (2012), Lee (2013), Amoozegar et al., (2017), Cui et al. (2017), Sahli et al., (2020), and Hwan, et al., (2021).

After washed aseptically with sterile ECM broth $(50 \mathrm{~mL})$, the contaminated beef jerky sample $(50 \mathrm{~g})$ was incubated at $37^{\circ} \mathrm{C}$ for 10 days in Erlenmeyer flasks of $250 \mathrm{~mL}$. After this period, rates of $1 \mathrm{~mL}$ were diluted in sterile $\mathrm{NaCl}$ solution at $20 \%$ and subsequently $0.1 \mathrm{~mL}$ of each dilution were seeded into agar ECM and incubated at $37^{\circ} \mathrm{C}$. The growth monitoring of the colonies formed selected the strains based on different macroscopic features, and depletion technique was applied to obtain pure cultures that were subsequently stored in ECM broth at $-4{ }^{\circ} \mathrm{C}$ to form a culture bank.

To reach and learn the optimum incubation period for the isolates and pre-inoculum preparation, a loop of each strain in pure culture solid medium was introduced into ECM broth with $20 \% \mathrm{NaCl}$ to generate the growth curve through optical density (OD) by turbidity in spectrophotometer by days of incubation. Growth was recorded every three days with absorbance in $600 \mathrm{~nm}$, subsequently considering the highest OD value as maximum growth. The experiment was performed in duplicate and the growth curves were generated on Microsoft Excel 2010.

\subsection{Macroscopic, microscopic identification, and physiological features of halophilic strains}

Colony morphology, opacity, margin, elevation, texture, and pigmentation were determined from the notations of their macroscopic features in solid medium after a 15 -day incubation at $37^{\circ} \mathrm{C}$.

For macroscopic identification of cell morphology, we used Gram staining technique as described by Dussault (1955), whose procedure involved fixing and simultaneously desalinating air-dried sheets in acetic acid at $2 \%$ for 5 min, followed by drying and staining according to standard procedures.

Catalase production was determined by adding an $\mathrm{H}_{2} \mathrm{O}_{2}$ solution at 3\% to the colonies in agar (Grant et al., 2001). The presence of oxidase was verified by observing the formation of violet color when spreading a colony on a piece of moist filter paper containing $1 \%$ tetramethyl-p-phenylenediamine dichloroiodate (Holding \& Collee, 1971).

\subsection{Effects of growth variables on halophilic strains}

To assess the growth features of the isolates, as proposed by Oren et al., (1997), we firstly determined the optimum $\mathrm{pH}$ range for the strains to grow by testing the isolates at different $\mathrm{pH}$ ranges $(5,7$, and 9) in ECM. Rates of diluted preinoculums $(100 \mu \mathrm{L})$ were inoculated into the media, and the cultures were then incubated at $37{ }^{\circ} \mathrm{C}$. The growth of the halophilic cultures was monitored for 15 days, the optimum $\mathrm{pH}$ value was determined after verifying the presence or absence of colony formation in the medium.

The determination was followed by response surface methodology with complete $2 \times 3$ factorial design generating eleven tests according to the methodology proposed by Box and Draper (1987), aiming to assess the influence of different concentrations of three variables: a source of organic components (yeast extract), magnesium $\left(\mathrm{MgCl}_{2}\right)$, and salinity $(\mathrm{NaCl})$ (independent variables) on the response variable, colony-forming units (CFU. $\mathrm{mL}^{-1}$ ) in solid ECM (item 2.2).

The concentrations of the variables were determined based on Schneegurt (2012), who described the different media and conditions for the growth of bacteria and halophilic and halotolerant archaea. Table 1 presents the experimental design and the coded and actual variables. 
Table 1 - Experimental design $2 \times 3$ for all strain growth tests.

\begin{tabular}{lllllll}
\hline \multirow{2}{*}{ Tests } & \multicolumn{3}{c}{ Coded variables } & \multicolumn{3}{c}{ Actual variables } \\
\cline { 2 - 7 } & $\mathrm{X}_{1}$ & $\mathrm{X}_{2}$ & $\mathrm{X}_{3}$ & $\mathrm{X}_{1}$ & $\mathrm{X}_{2}$ & $\mathrm{X}_{3}$ \\
\hline 1 & +1 & +1 & +1 & 10 & 35 & 300 \\
2 & -1 & -1 & +1 & 1 & 10 & 300 \\
3 & +1 & -1 & +1 & 10 & 10 & 300 \\
4 & -1 & +1 & +1 & 1 & 35 & 300 \\
5 & +1 & +1 & -1 & 10 & 35 & 100 \\
6 & -1 & +1 & -1 & 1 & 35 & 100 \\
7 & +1 & -1 & -1 & 10 & 10 & 100 \\
8 & -1 & -1 & -1 & 1 & 10 & 100 \\
9 & 0 & 0 & 0 & 5 & 25 & 200 \\
10 & 0 & 0 & 0 & 5 & 25 & 200 \\
11 & 0 & 0 & 0 & 5 & 25 & 200 \\
\hline
\end{tabular}

$\mathrm{X}_{1}=$ Yeast extract; $\mathrm{X}_{2}=\mathrm{MgCl}_{2}$ and $\mathrm{X}_{3}=\mathrm{NaCl}$, in $\mathrm{g} \mathrm{L}^{-1}$. Source: Authors.

Table 1 shows the different concentrations of the variables used in studies for the 11 tests performed in coded variables $(-1,0$, and -1$)$ and the variables with actual values in $\mathrm{g} \mathrm{L}^{-1}$.

At first, the halophilic strains grew in ECM broth at $37{ }^{\circ} \mathrm{C}$ until reaching optimum growth (determined by optical density) as established by the growth curve for the pre-inoculum generation.

We counted the halophiles through direct plating by performing serial dilutions up to $10^{-6}$ from the pre-inoculum and subsequently distributing rates of $0.1 \mathrm{~mL}$ of each dilution using a drigalski loop on the plates containing the agar ECM with the variations of yeast extracts $\mathrm{MgCl}_{2}$ and $\mathrm{NaCl}$. All 11 tests were performed in triplicate and incubated at $37{ }^{\circ} \mathrm{C}$ for 15 days followed by the counting of colonies.

The optimization model was estimated by including the interaction effect according to the coefficient of determination $\left(r^{2}\right)$, above $70 \%$, allowing to infer that the model explains the high percentage of total variability. The analyses of results were performed on the Statistica 7.0 software.

\section{Results and Discussion}

\subsection{Determining the macroscopic, microscopic, and physiological features of isolated beef jerky halophilic strains.}

Halophiles are organisms that are highly salt-preferred and inhabit hypersaline environments. Prokaryotic and eukaryotic microorganisms may have the capacity to balance the osmotic pressure of saline media and resist denaturation (Singh and Singh, 2018). Salty and fermented food products generally contain halophilic archaea that develop at high concentrations of $\mathrm{NaCl}$ and may cause the product to deteriorate even at high concentrations (Lorentzen et al., 2015; Lee, 2013; Moschetti et al., 2006).

Two isolates, C11 and V22A strains, were generated from the beef jerky sample in visible deteriorating condition (Figure 1) after 15 days of incubation based on color, size, and consistency. The strains were isolated in pure culture media subjected to physiological and morphological tests. 
Figure 1 - Samples of beef jerky contaminated with haloarchaea.
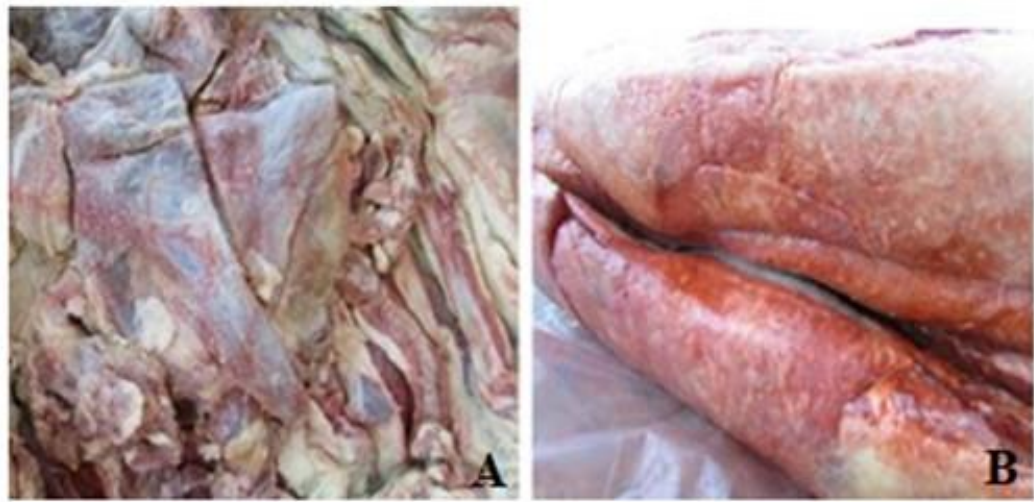

Source: Authors.

The isolated strains presented varied colony features. The C11 isolate showed a white cream color, round translucent colonies with a spiral margin and convex elevation, while V22 had red pigmentation, punctiform opaque colonies, full-margin, and full elevation. Figure 2 illustrates all isolated strains.

Figure 2 - Morphological features of the isolated strains (A) and in pure culture (B).

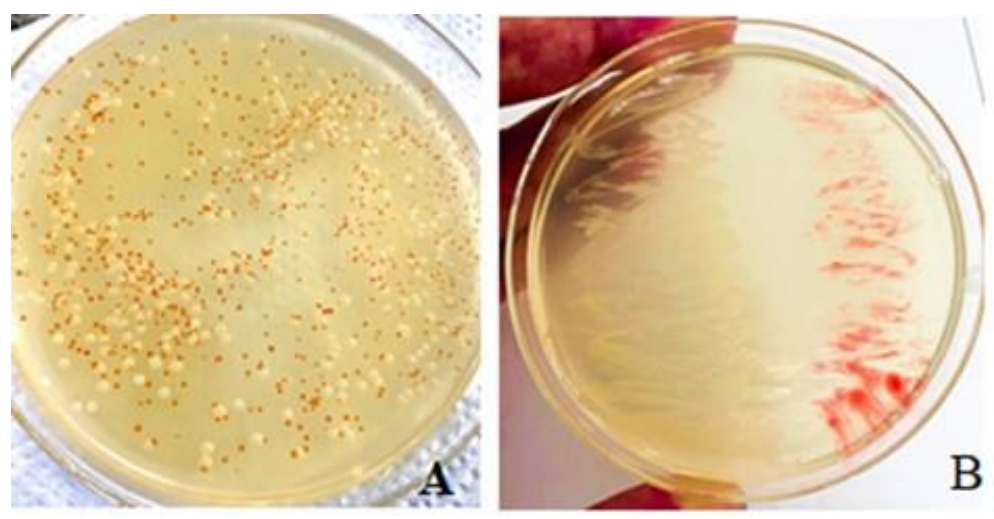

Source: Authors (2021).

As for the morphological cell features, the C11 strain presented colloid shape, and the V22 strain showed polymorphic cells (stick- or cocci-shaped); both strains were gram-negative (figure 3 ) and catalase and oxidase positive. Table 2 presents a summary of the morphophysiological features of the isolated strains in $20 \% \mathrm{NaCl}$ medium; these properties, along with the colony pigmentation and need of high salt concentrations, suggest that the isolates are members of the Halobacteriaceae family (Hasan and Mohammadian, 2011). Singh and Singh (2018) described the isolation of thirteen halophilic archaea from a saline environment in India where the colonies featured different red shades, Gram-negative, and growth in culture medium at saturating concentration of $\mathrm{NaCl}(35 \%$ ), which indicates the existence of haloarchaea. Cui et al. (2017) found rod-shaped archaea, Gram-negative, and colonies with red pigmentation. In general, halophilic archaea are red due to the presence of $\mathrm{C}_{50}$ carotenoids (bacterioruberines) (Williams, 1989). 
Table 2 - Morphological and physiological features of the halophilic strains.

\begin{tabular}{lcc}
\hline Features & C11 & V22 \\
\hline Colony shape & Round & Punctiform \\
Opacity & Translucent & Opaque \\
Margin & Spiral & Full \\
Elevation & Convex & Complete \\
Texture & Creamy & Mucous \\
Color & White cream & Red \\
Cell morphology & Cocus & Polymorphic \\
Catalase & + & + \\
Oxity & + & + \\
Gram & - & - \\
\hline
\end{tabular}

(-) Negative; (+) Positive. Source: Authors.

Figure 3 - Microscopy of the isolates after Gram color of the C11 (A) and V22 (B) strains.

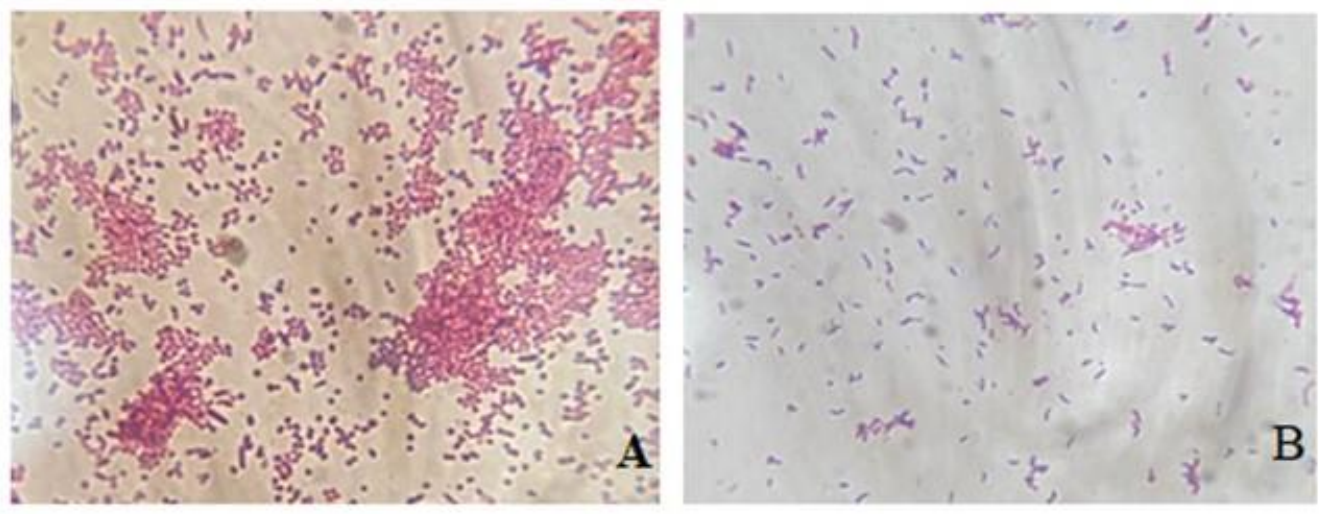

Source: Authors.

Okmen and Arslan (2019) isolated archaea from the Lake Tuz (Turkey) and found creamy color. Salgaonkar and Rodrigues (2019) obtained isolates from iodized salt from India and observed colonies with different shades of yellow, orange, and red after 30 days of incubation, with the possibility of pigmented and non-pigmented halophiles. Enquahone et al. (2020) explain that red spots in meat, animal skins, and other salty products may indicate microbial contamination of halophile in the product. In general, the production of pigment in halophilic archaea in culture medium is known to start in the end of the growth phase, in some cases after two weeks.

As well as the growth conditions of haloarchaea directly affect the morphological features of cells, organisms may vary in the size of cells between 0.8 and $13 \mu \mathrm{m}$ and appear in cells that are generally pleomorphic and often with elongated, round, disk, and trapezoid shapes. Mos of the species of Haloferax and Haloarcula are generally of pleomorphic nature. Specific studies generally consider Haloarchaea as Gram-negative, except halococos and the members of the Natronococcus genus, which also have variation between Gram-positive and negative (Oren, 2014; Kumar and Tiwari, 2019).

Haloarchaea are generally isolated from different ecosystems, such as salt lakes (Birbir et al.,2007), the Dead Sea (Oren and Shilo, 1981), salt lakes in Iran (Hasan and Mohammadian, 2011), and commercial salt (Minegishi et al., 2015). New types of halophilic archaea have also been discovered in food like fermented fish and fish sauces that require large amounts of salt, especially in Korea, Japan, and countries of the Southeast Asia (Akolkar et al., 2010; Lee, 2013). In Brazil, few reports are available in the literature addressing the haloarchaea present in beef jerky, a typically Brazilian product.

Savage et al., (2007), Singh and Singh (2018), Sahli et al. (2020), Hwang et al. (2021), as well as other aforementioned authors, corroborate the results found for the morphological and physiological features of the isolated strains used in this study. 
The growth curve of the isolates demonstrates that both strains have a standard growth, which was important to establish the optimum incubation time. Figure 4 illustrates the growth curve generated by the mean of the optical density (OD) measure in $1 \mathrm{~mL}$ medium over 20 days.

Figure 4 - Growth curves of the $\mathrm{C} 11$ and V22 strains in $20 \% \mathrm{NaCl}$ ECM medium as function of the values generated through optical density.

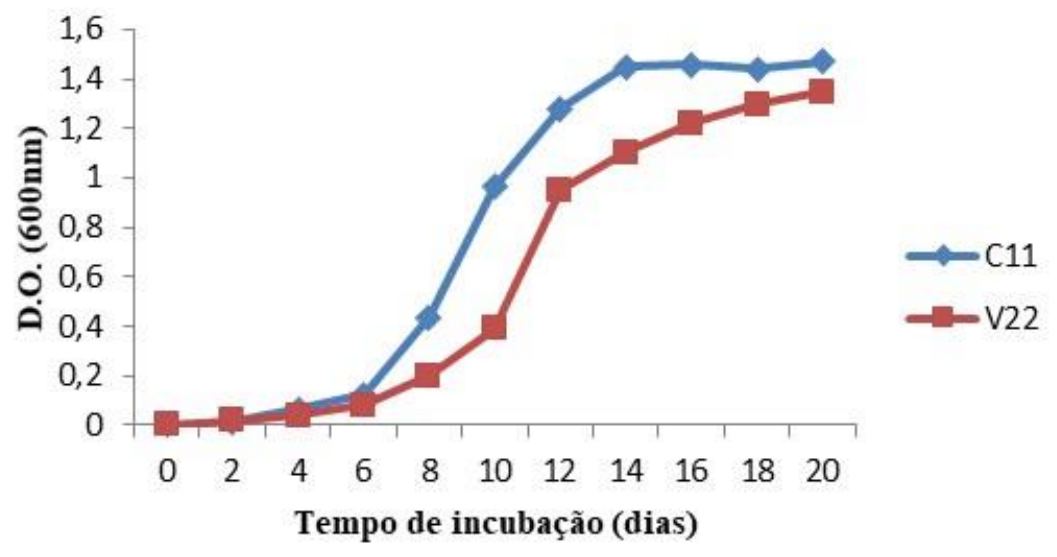

Source: Authors (2021).

Figure 4 shows that the $\mathrm{C} 11$ strain has a faster cell growth than the V22 strain, and the logarithmic growth (log phase) of $\mathrm{C} 11$ occurred from the sixth day reaching maximum growth around the fifteenth day (DO=1.46). Despite the late start of the $\log$ phase, the V22 strain reached maximum growth around the sixteenth incubation day (DO=1.105), after this period, both strains approached their stationary phases; therefore, the period of incubation fifteen days for the isolates should be considered. The decline phase was not observed since turbidimetry is not able to distinguish between living and dead cells in the culture medium (Tortora et al., 2017).

Such results are in line with the literature reports since, according to Schneegurt (2012), halophilic archaea generally present a relatively slow growth rate comparing with bacteria; therefore, the low growth rate of certain species may require incubation periods of up to two months to achieve optimum results. Cui et al. (2017) applied one month of incubation for their halophilic strains isolated from a solar salt pan in China; Sahli et al. (2020), in turn, described the growth of halophilic strains isolated from saline soil in Algeria for 7 days, while Enquahone et al. (2020) and Stan-Lotter (2002) applied 15 days as optimum incubation period.

\subsection{Determining the effects of variables on the growth of halophilic strains}

Concentrations of $\mathrm{NaCl}, \mathrm{MgCl}_{2}, \mathrm{pH}$, and temperature are the main factors responsible for the growth of haloarchaea in hypersaline environments (Oren et al., 1997).

The tests performed using different $\mathrm{pH}$ ranges revealed the growth of colonies from both strains in medium with $\mathrm{pH}$ 7 (neutrophilic), while the other tested ranges found no formation of colonies after 15 incubation days.

$\mathrm{Xu}$ et al. (2019) assessed the growth of Haloprofundus halophilus sp. in liquid medium at pH range between 5.010.0 at intervals of $0.5 \mathrm{pH}$ units and found that the species were able to grow at $\mathrm{pH}$ 6.5-9.5, with optimum $\mathrm{pH}$ at 7.0. Cui et al. (2017) isolated a halophilic strain of archaea, YGH44T, from sea salt from Yinggehai, in the province of Hainan, China, and the optimum growth was reached at $\mathrm{pH} 7.0$ (range: $\mathrm{pH}$ 5.0-9.0). Hasan et al. (2011) also reported pH 7 as optimum for the growth of Halobacterium salinarum isolated from a solution from salt lakes in Iran. 
Amoozegar et al. (2017) described that haloarchaea can grow at a pH range of 5.5 a 11. Haloarchaea are adapted to survive at a larger $\mathrm{pH}$ range, slightly acid, neutral to alkaline. Most isolated members from different habitats are neutrophilic or alkaliphilic, while acidophilic haloarchaea are fairly limited (Kumar and Tiwari, 2019).

Optimum $\mathrm{pH}$ range for the growth of the isolates in our research corroborates the reports of the aforementioned authors, as well as the environment where they were isolated, since the $\mathrm{pH}$ of beef jerky is neutral, varying from 6.3 to 7.0 (Paim, et al., 2017).

A complete $2 \times 3$ factorial design assessed the influence of different concentrations of a source of organic components (yeast extract), magnesium $\left(\mathrm{MgCl}_{2}\right)$ and salinity $(\mathrm{NaCl})$ (independent variables) aiming to optimize the optimal growth conditions of halophilic strains. The results show that in the tests $1,2,3$, and 4 , with $\mathrm{NaCl}$ concentration of $300 \mathrm{~g} \mathrm{~L}^{-1}$, the $\mathrm{C} 11$ strain was not able to grow, while in the tests $5,6,7$, and 8 , with $\mathrm{NaCl}$ concentration of $100 \mathrm{~g} \mathrm{~L}^{-1}$, the V22 strain showed no growth, as well as the subsequent tests revealed the optimal growth conditions for the isolates from positive tests.

For optimization, results without significance were disregarded, generating adjusted models using coded variables (table 1). The adjustments of the models can be understood through the coefficient of determination $\left(\mathrm{R}^{2}\right)$ exemplified between 70 and $93 \%$ of variance between the responses.

Figures 5 (a) and (b) present the effects of concentrations of $\mathrm{NaCl}$ and yeast extract and $\mathrm{NaCl}$ e $\mathrm{MgCl}_{2}$ concentrations on the C11 strain growth. It is known that it is indispensable to determine the growth of halophilic archaea parameters, like salinity, magnesium chloride, and source of organic compounds.

The results in figure 5 (a) for the $\mathrm{C} 11$ strain growth demonstrate that the interaction between $\mathrm{NaCl}$ and yeast extract parameters had significant influence on growth; therefore, experiments containing values of $200 \mathrm{~g} \mathrm{~L}^{-1} \mathrm{NaCl}_{\text {, and } 5 \mathrm{~g} \mathrm{~L}}^{-1}$ of yeast extract are optimum growth values, since the optimum region for the "growth" attribute is close to the central point, between 2.5 and $8 \mathrm{~g} \mathrm{~L}^{-1}$, for the "yeast extract" variable, and between 100 and $150 \mathrm{~g} \mathrm{~L}^{-1}$ for the "NaCl" variable. According to the experimental design, Figure 5 (b) shows that the increase in growth was favored by the mean concentrations of $\mathrm{NaCl}$ and $\mathrm{MgCl}_{2}$, both reaching significant effect, since the optimum growth region occurred between 14 and $26 \mathrm{~g} \mathrm{~L}^{-1}$ for $\mathrm{MgCl}_{2}$ and from 100 to $150 \mathrm{~g} \mathrm{~L}^{-1}$ for $\mathrm{NaCl}$. Thus, the concentrations in the central point of the experiment become optimum growth values. This study found no significant interactions between yeast extract and $\mathrm{MgCl}_{2}$. The surfaces presented $\mathrm{R}^{2}$ of 0.98 in figure 5 (a) and 0.95 in figure $5(\mathrm{~b})$, thus demonstrating good data correlation.

Figure 5 - Response surface for (a) $\mathrm{NaCl}$ and yeast extract in $\left(\mathrm{g} \mathrm{L}^{-1}\right)$ and (b) $\mathrm{NaCl}$ and $\mathrm{MgCl}_{2}$ in $\left(\mathrm{g} \mathrm{L}^{-1}\right)$, and in relation to growth of halophilic strains $\mathrm{C} 11\left(\mathrm{CFU} \mathrm{mL} \mathrm{m}^{-1} \times 10^{6}\right)$.

(a)

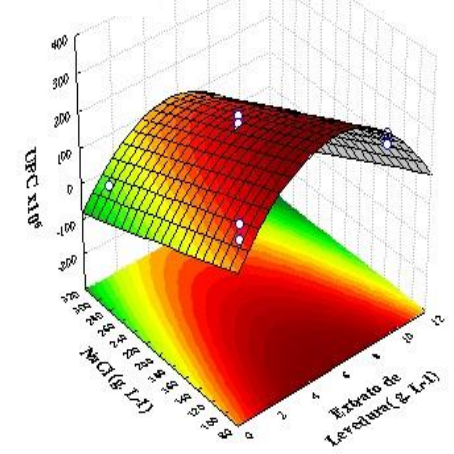

(b)

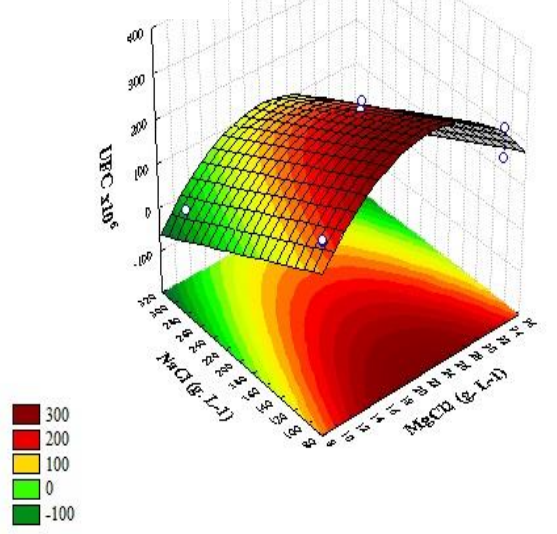

(1)


Figures 6 (a), (b) and (c) illustrate the effects of concentrations of $\mathrm{NaCl}$ and yeast extract, $\mathrm{NaCl}$ and $\mathrm{MgCl}_{2}$, and $\mathrm{MgCl}_{2}$ and yeast extract on the V22 strain growth, respectively. The results show significant interactions among all variables assessed for the V22 strain. Figure 6 (a) indicates that both $\mathrm{NaCl}$ and yeast extract were significant variables in response to strain growth with values between 250 and $300 \mathrm{~g} \mathrm{~L}^{-1}$ and $5.5 \mathrm{~g} \mathrm{~L}^{-1}$, respectively, as optimum growth. Another significant interaction is found in figure 6 (b), showing significant values for the $\mathrm{NaCl}$ and $\mathrm{MgCl}_{2}$ variables, and in figure 6 (c), with significance indicated between $\mathrm{MgCl}_{2}$ and yeast extract, thus demonstrating that $35 \mathrm{~g} \mathrm{~L}^{-1}$ of $\mathrm{MgCl}_{2}$ as optimum growth. By observing and comparing figures 6 (a) (b), and (c), we find that the significant values are within the same range in all charts of response surface. The surfaces presented $R^{2}$ of 0.81 in figure $6(\mathrm{a}), 0.73$ in figure 6 (b), and 0.87 in figure 6 (c), also indicating good data correlation.

Figure 6 - Response surface for (a) $\mathrm{NaCl}$ and yeast extract and (b) $\mathrm{NaCl}$ and $\mathrm{MgCl}_{2}\left(\mathrm{~g} \mathrm{~L}^{-1}\right)$ and (c) $\mathrm{MgCl}_{2}$ and yeast extract in relation to growth of halophilic strains $\mathrm{V} 22\left(\mathrm{CFU} \mathrm{mL} \mathrm{m}^{-1} \times 10^{4}\right)$.
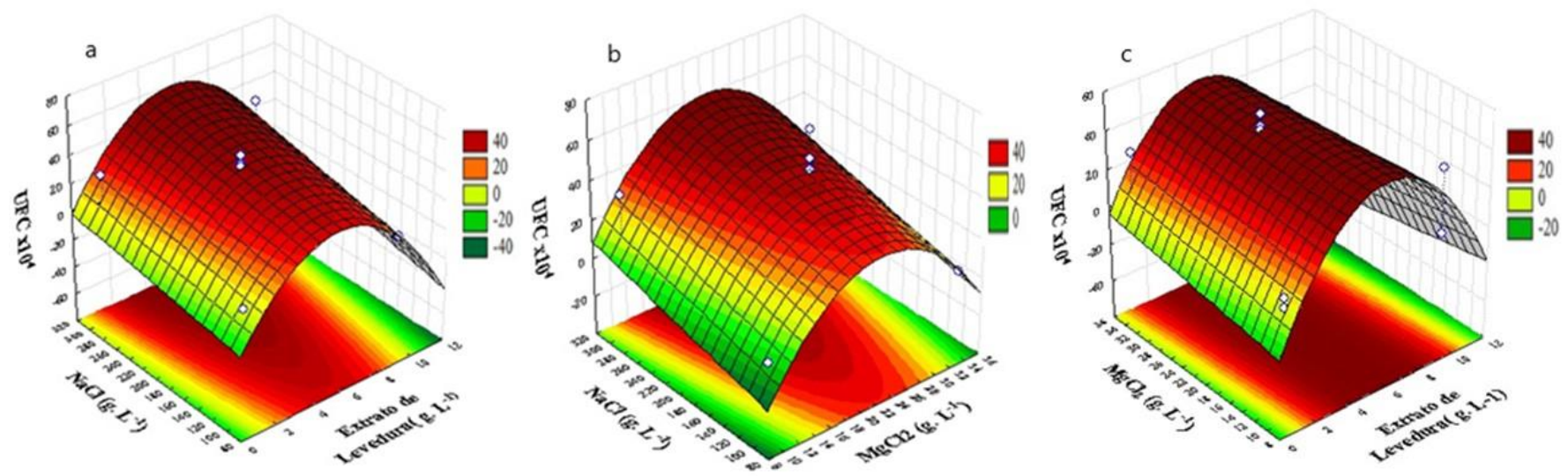

Source: Authors.

Halophiles are organisms that require high $\mathrm{NaCl}$ levels; the literature reports that these microorganisms initially need at least $10 \%$ of sodium chloride and some may even survive in salt crystals. Sodium ions are essential to maintain cell integrity for following the external surface of cell wall of the Halobacterium genus; thus, when subjected to an environment with low $\mathrm{Na}^{+}$concentrations, cell lysis occurs. These organisms are adapted to maintain high concentrations of other solutes in their cytoplasm to ensure the integrity of osmotic balance with the outside world (DaSarma \& Arora, 2002; Oren, 2002).

This study tested three different $\mathrm{NaCl}$ concentrations on the growth of isolates through experiments that indicated the capacity of the C11 strain to grow between 100 and $200 \mathrm{~g} \mathrm{~L}^{-1}$, and the V22 strain in 200 and $300 \mathrm{~g} \mathrm{~L}^{-1}$, both classified as extreme halophilic.

Sahli et al. (2020) reported that all isolates were extreme halophilic and required at least $15 \%$ salinity, growing optimally in 20-25\%, while Minegishi et al. (2015) described that Halococcus agarilyticus was able to grow in 24-30\% $\mathrm{NaCl}$ (optimum, 27\%). Singh and Singh (2018) reported that the optimum NaCI concentration for thirteen halophilic archaea from a saline environment in Western India was 20-25\%. These results are similar to the values found in this study. Although this source of organic compound is generally added in low amounts to the media, it is fundamental for being rich in vitamins and other growth factors that stimulate microbial growth (Schneegurt, 2012). By weighting the results obtained, we established that the strains presented optimum growth in $5 \mathrm{~g} \mathrm{~L}^{-1}$. Our data are supported by the findings of Birbir et al. (2007), who reported halophilic strains growing optimally at the concentration of $0.5 \%$. The authors used different concentrations of yeast extracts, 
from 0.1\% (Sahli et al., 2020; Minegishi et al., 2015), $0.5 \%$ (Mullakhanbhai and Larsen, 1975; Rodriguez-Valera et al., 1980; Tomlinson andHochstein,1972) to $1 \%$ (Singh and Singh, 2018), all tested in experiments.

Microorganisms require $\mathrm{Mg}$ salts, and halotolerant and halophilic strains need much more $\mathrm{Mg}^{2+}$ to grow; however, their growth can be inhibited by higher concentrations of $\mathrm{Mg}^{2+}$, a divalent cation that keeps the morphology cell stable. The formulation of the media for haloarchaea applied concentrations of 2-5\% of Mg salts, which can be chloride (more popular), sulfide, or nitrate of magnesium (Schneegurt, 2012). The literature reports the concentrations of 0.6-0.9 M for halophilic cultures (Okmen \& Arslan, 2019). As shown, these studies support the results obtained from the experiments reporting the value of $2.5 \%$ as optimum growth.

Vidyasagar et al., (2007) determined the optimum concentration of $\mathrm{MgCl}_{2}$ for growth and production of protease, in which an increase in salt concentration enhanced enzyme growth and production, reaching a peak at $0.5 \mathrm{M}$; however, the concentration of $1 \mathrm{M}$, or higher, inhibited growth. Makhdoumi-Kakhki et al. (2012) isolated Halovenus aranensis from the salt in Lake Aran-Bidgol, in Iran, and determined the need of $\mathrm{MgCl}_{2}$ for growth in medium containing $\mathrm{MgCl}_{2}$ in $0-1 \mathrm{M}$ at intervals of $0.05 \mathrm{M}$, respectively. Magnesium was necessary for growth within the interval 0.1-1 $\mathrm{M}$, and optimum growth occurred at $0.5 \mathrm{M}$.

In general, the literature reports are consistent with the results found in these studies. Finally, figures 7 and 8 show the results of the desirability test presenting the specifications (minimum, optimum, and maximum) of the results generated for the optimized tests regarding the proportions of yeast extract, $\mathrm{NaCl}$, and $\mathrm{MgCl}_{2}$ for the optimized preparation of the culture media for the strains.

Thereby, as in figures 7 and 8, for optimum desirability values, the optimal adjustments of the factors are 5.3 and 5.5 $\mathrm{g} \mathrm{L}^{-1}$ yeast extract, 23.1 and $35 \mathrm{~g} \mathrm{~L}^{-1} \mathrm{MgCl}_{2}$, and 200 and $300 \mathrm{~g} \mathrm{~L}^{-1} \mathrm{NaCl}$ for the $\mathrm{C} 11$ and $\mathrm{V} 22$ strains, respectively. As described by Bianchin, Yamashita, and Benassi (2017), the optimum parameters reported for desirability are distributed in the red vertical lines of charts corresponding to the optimum values of the parameters studied, thus considering the tests 9,10 , and 11 for the $\mathrm{C} 11$ and test 1 for V22. 
Figure 7 - Profile of optimized values through desirability test for potential of yeast extract, $\mathrm{NaCl}$, and $\mathrm{MgCl}_{2}$ for $\mathrm{C} 11$ strain growth.
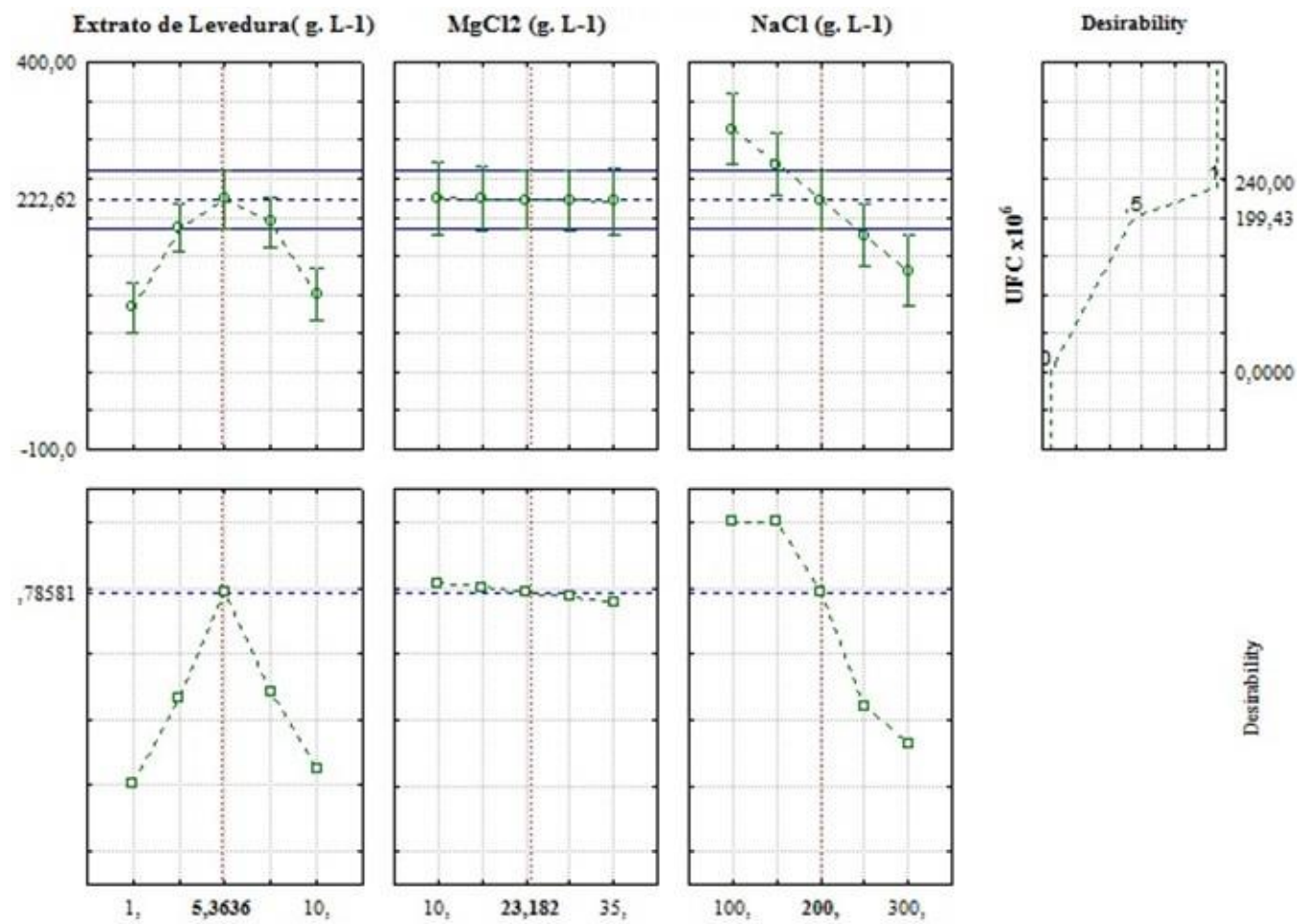

商

Figure 8 - Profile of optimized values through desirability test for potential of yeast extract, $\mathrm{NaCl}$, and $\mathrm{MgCl}_{2}$ for $\mathrm{V} 22$ strain growth.
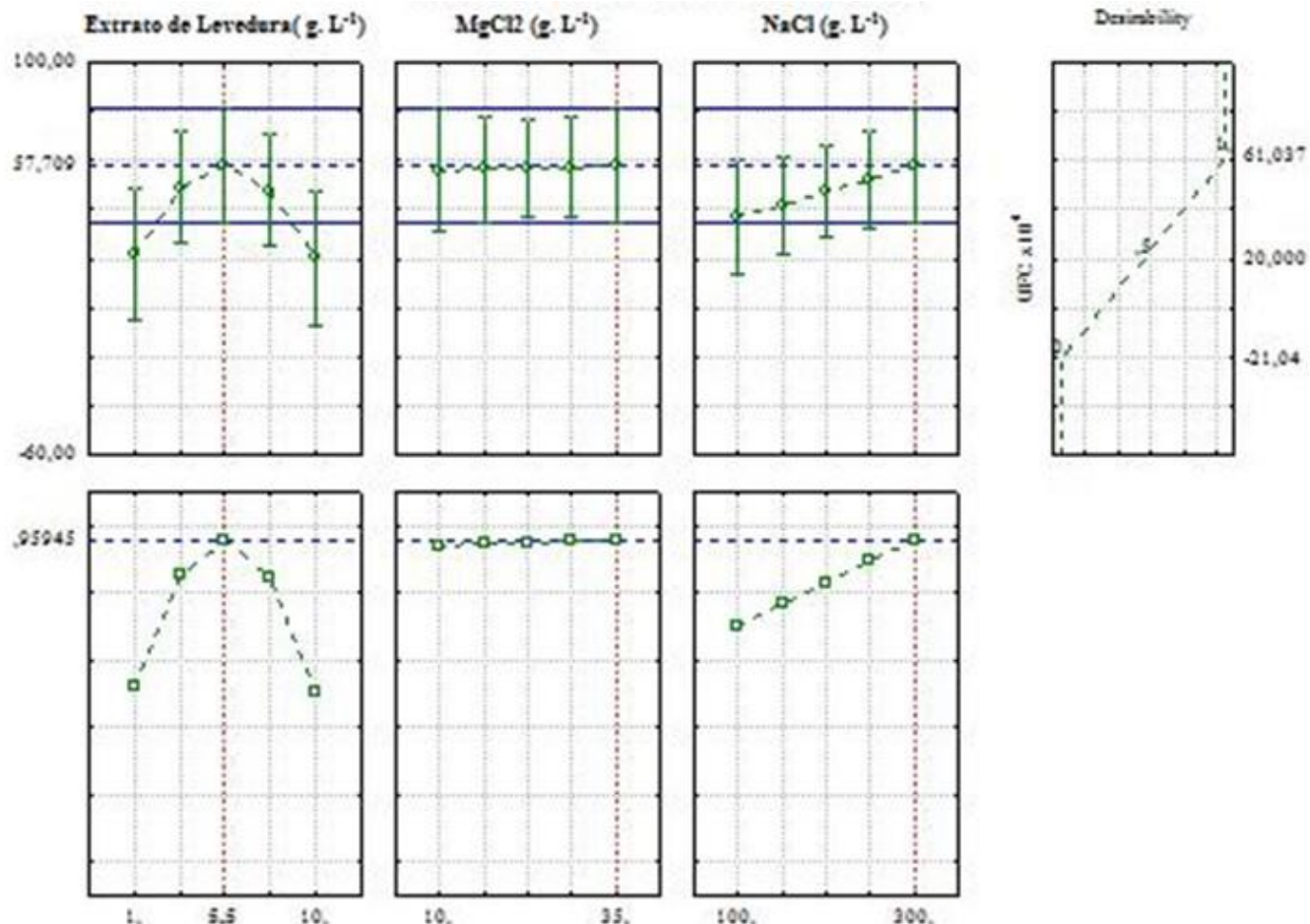

Source: Authors. 


\section{Conclusion}

We conclude that the two halophilic strains obtained from beef jerky in deteriorating condition are organisms belonging to the Archaea domain of the Halobacteria class due to their typical features, as Gram-negative, catalase, and oxidase negative, cocci-shaped (C11) and pleomorphic (V22) cell morphologies, in addition to relatively slow growth rate from the log phase after 6-8 days of incubation. Still, the lineages were neutrophilic, and no growth was observed in medium with pH 5 and 9.

The design allows to establish that the strains are extremophilic reaching optimal growth from 200 to $300 \mathrm{~g} \mathrm{~L}^{-1}$ (3.4 M) $\mathrm{NaCl}$ and 25 at $35 \mathrm{~g} \mathrm{~L}^{-1} \mathrm{MgCl}_{2}$ and requiring $5 \mathrm{~g} \mathrm{~L}^{-1}$ yeast extract, based on the results of our experimental design, thus supporting the hypothesis that different culture conditions may influence the growth of halophilic archaea.

It is essential to know the morphophysiological and biochemical features of strains when aiming to establish obstacles for the proliferation and deterioration of por these organisms in salted meat products. Despite the great attention gained by the isolation of halophilic archaea from hypersaline environments worldwide over the past decades, few studies were performed focusing on beef jerky since research of this nature concentrate especially on salt lakes.

Studies are needed to evaluate and estimate the production of hydrolytic exoenzymes and to assess the sensitivity of these spoilage microorganisms isolated from jerked beef in relation to organic acid preservatives.

\section{References}

Akolkar, A. V., Durai, D., \& Desai, A. J. (2010). Halobacterium sp. SP1 as starter culture for accelerating fish sauce fermentation. Journal of applied microbiology, 109(1), 44-53.

Amoozegar, M. A., Siroosi, M., Atashgahi, S., Smidt, H., \& Ventosa, A. (2017). Systematics of haloarchaea and biotechnological potential of their hydrolytic enzymes. Microbiology, 163(5), 623-645.

Bianchin, M., Yamashita, F., \& Benassi, M. D. T. (2017). Microwave assisted saponification for diterpenes extraction in roasted arabica coffee. Química Nova, 40(9), 1039-1044.

Birbir, M., Calli, B., Mertoglu, B., Bardavid, R. E., Oren, A., Ogmen, M. N., \& Ogan, A. (2007). Extremely halophilic Archaea from Tuz Lake, Turkey, and the adjacent Kaldirim and Kayacik salterns. World Journal of Microbiology and Biotechnology, 23(3), 309-316.

Box, G. E., \& Draper, N. R. (1987). Empirical model-building and response surfaces. John Wiley \& Sons.

Brasil. (2020). Instrução Normativa $N^{o}$ 92, de 18 de setembro de 2020. Dispõe Sobre a Identidade e os Requisitos de Qualidade do Charque, da Carne Salgada Curada Dessecada, do Miúdo Salgado Dessecado e do Miúdo Salgado Curado Dessecado. https://www.in.gov.br/en/web/dou/-/instrucao-normativan-92-de-18-de-setembro-de-2020-278692460

Caglayan, P., Birbir, M. E. R. A. L., Sanchez-Porro, C., \& Ventosa, A. (2017). Screening of industrially important enzymes produced by moderately halophilic bacteria isolated from salted sheep skins of diverse origin. Journal of the American Leather Chemists Association, 112(06), 207-216.

Cui, H. L., Lü, Z. Z., Li, Y., \& Zhou, Y. (2017). Salinirussus salinus gen. nov., sp. nov., isolated from a marine solar saltern. International journal of systematic and evolutionary microbiology, 67(9), 3622-3626.

DaSarma, S., \& Arora, P. (2002). Halophiles. Encyclopedia of life sciences. London. Nature Publishing Group, 8, 458-466.

Dussault, H. P. (1955). An improved technique for staining red halophilic bacteria. Journal of bacteriology, 70(4), 484-485.

Enquahone, S., van Marle, G., Gessesse, A., \& Simachew, A. (2020). Molecular identification and evaluation of the impact of red heat damage causing halophilic microbes on salted hide and skin. International Biodeterioration \& Biodegradation, 150, 104940.

Grant, W. D. (2001). Class III. Halobacteria class nov. Bergey's manual of systematic bacteriology, 1, 294-301.

Gupta, R. S., Naushad, S., \& Baker, S. (2015). Phylogenomic analyses and molecular signatures for the class Halobacteria and its two major clades: a proposal for division of the class Halobacteria into an emended order Halobacteriales and two new orders, Haloferacales ord. nov. and Natrialbales ord. nov., containing the novel families Haloferacaceae fam. nov. and Natrialbaceae fam. nov. International Journal of Systematic and Evolutionary Microbiology, 65(Pt_3), 10501069 .

Hasan, S. M., \& Mohammadian, J. (2011). Isolation and characterization of Halobacterium salinarum from saline lakes in Iran.

Holding, A. J., \& Collee, J. G. (1971). Chapter I Routine biochemical tests. In Methods in microbiology (Vol. 6, pp. 1-32). Academic Press.

Hwang, C. Y., Cho, E. S., Yoon, D. J., \& Seo, M. J. (2021). Halobellus ruber sp. nov., a deep red-pigmented extremely halophilic archaeon isolated from a Korean solar saltern. Antonie van Leeuwenhoek, 1-15. 
Kumar, V., \& Tiwari, S. K. (2019). Halocin diversity among Halophilic Archaea and their applications. In Microbial diversity in ecosystem sustainability and biotechnological applications (pp. 497-532). Springer, Singapore.

Lee, H. S. (2013). Diversity of halophilic archaea in fermented foods and human intestines and their application. Journal of Microbiology and Biotechnology, $23(12), 1645-1653$.

Inguglia, E. S., Zhang, Z., Tiwari, B. K., Kerry, J. P., \& Burgess, C. M. (2017). Salt reduction strategies in processed meat products-A review. Trends in Food Science \& Technology, 59, 70-78.

Lorentzen, G., Breiland, M. S. W., Østli, J., Wang-Andersen, J., \& Olsen, R. L. (2015). Growth of halophilic microorganisms and histamine content in dried salt-cured cod (Gadus morhua L.) stored at elevated temperature. LWT-Food Science and Technology, 60(1), 598-602.

Madigan, M. T., Martinko, J. M., Bender, K. S., Buckley, D. H., \& Stahl, D. A. (2016). Microbiologia de Brock-14 ${ }^{a}$ Edição. Artmed Editora.

Makhdoumi-Kakhki, A., Amoozegar, M. A., \& Ventosa, A. (2012). Halovenus aranensis gen. nov., sp. nov., an extremely halophilic archaeon from AranBidgol salt lake. International Journal of Systematic and Evolutionary Microbiology, 62(Pt_6), 1331-1336.

Minegishi, H., Echigo, A., Shimane, Y., Kamekura, M., Itoh, T., Ohkuma, M., \& Usami, R. (2015). Halococcus agarilyticus sp. nov., an agar-degrading haloarchaeon isolated from commercial salt. International Journal of Systematic and Evolutionary Microbiology, 65(Pt_5), 1634-1639.

Moschetti, G., Aponte, M., Blaiotta, G., Casaburi, A., Chiurazzi, M., Ventorino, V., \& Villani, F. (2006). Characterization of halophilic Archaea isolated from different hypersaline ecosystems. Annals of Microbiology, 56(2), 119-127.

Mullakhanbhai, M. F., \& Larsen, H. (1975). Halobacterium volcanii spec. nov., a dead dea halobacterium with a moderate salt requirement. Archives of Microbiology, 104(1), 207-214.

Okmen, G., \& Arslan, A. (2019). The effects of environmental conditions on growths of halophilic archaea isolated from Lake Tuz. International Journal of Environmental Science and Technology, 16(9), 5155-5162.

Oren, A. (2002). Adaptation of halophilic archaea to life at high salt concentrations. In Salinity: environment-plants-molecules (pp. 81-96). Springer, Dordrecht.

Oren, A. (2014). Taxonomy of halophilic Archaea: current status and future challenges. Extremophiles, 18(5), 825-834.

Oren, A., \& Shilo, M. (1981). Bacteriorhodopsin in a bloom of halobacteria in the Dead Sea. Archives of Microbiology, $130(2), 185-187$.

Oren, A., Ventosa, A., \& Grant, W. D. (1997). Proposed minimal standards for description of new taxa in the order Halobacteriales. International Journal of Systematic and Evolutionary Microbiology, 47(1), 233-238.

Paim, B. T., Leães, Y. S. V., Vargas, P. R. M. C., \& da Silva, L. R. (2017). Análise bromatológica do charque de agroindústrias com sistema de inspeção sisbipoa no município de Alegrete/RS. Revista da Jornada de Pós-Graduação e Pesquisa-Congrega Urcamp, 520-523.

Paixão, G. C., Pantoja, L. D. M., Brito, E. H. S., \& Mourão, C. B. I. (2015). Desvendando o mundo invisível da microbiologia. EdUECE,

Picchi, V. (2015). História, ciência e tecnologia da carne bovina. Paco Editorial.

Quadri, I., Hassani, I. I., l'Haridon, S., Chalopin, M., Hacène, H., \& Jebbar, M. (2016). Characterization and antimicrobial potential of extremely halophilic archaea isolated from hypersaline environments of the Algerian Sahara. Microbiological Research, 186, 119-131.

Rodriguez-Valera, F., Ruiz-Berraquero, F., \& Ramos-Cormenzana, A. (1980). Isolation of extremely halophilic bacteria able to grow in defined inorganic media with single carbon sources. Microbiology, 119(2), 535-538.

Sahli, K., Gomri, M. A., Esclapez, J., Gómez-Villegas, P., Ghennai, O., Bonete, M. J., \& Kharroub, K. (2020). Bioprospecting and characterization of pigmented halophilic archaeal strains from Algerian hypersaline environments with analysis of carotenoids produced by Halorubrum sp. BS2. Journal of Basic Microbiology, 60(7), 624-638.

Salgaonkar, B. B., \& Rodrigues, R. (2019). A Study on the Halophilic Archaeal diversity from the food grade iodised crystal salt from a saltern of India. Microbiology, 88(6), 709-719.

Savage, K. N., Krumholz, L. R., \& Oren, A., \& Elshahed, M. S. (2007). Haladaptatus paucihalophilus gen. nov., sp. nov., a halophilic archaeon isolated from a low-salt, sulfide-rich spring. International Journal of Systematic and Evolutionary Microbiology, 57(1), 19-24.

Schneegurt, M. A. (2012). Media and conditions for the growth of halophilic and halotolerant bacteria and archaea. In Advances in understanding the biology of halophilic microorganisms (pp. 35-58). Springer, Dordrecht.

Singh, A., \& Singh, A. K. (2018). Isolation, characterization and exploring biotechnological potential of halophilic archaea from salterns of western India. 3 Biotech, 8(1), 1-15.

Stan-Lotter, H., Pfaffenhuemer, M., Legat, A., Busse, H. J., Radax, C., \& Gruber, C. (2002). Halococcus dombrowskii sp. nov., an archaeal isolate from a Permian alpine salt deposit. International Journal of Systematic and Evolutionary Microbiology, 52(5), $1807-1814$.

Tomlinson, G. A., \& Hochstein, L. I. (1972). Isolation of carbohydrate-metabolizing, extremely halophilic bacteria. Canadian journal of microbiology, 18(5), $698-701$.

Tortora, G, Case, C, \& Funke, B (2017). Microbiologia. Artmed. 
Research, Society and Development, v. 11, n. 3, e21511326368, 2022

(CC BY 4.0) | ISSN 2525-3409 | DOI: http://dx.doi.org/10.33448/rsd-v11i3.26368

Vidal, V. A., Biachi, J. P., Paglarini, C. S., Pinton, M. B., Campagnol, P. C., Esmerino, E. A., \& Pollonio, M. A. (2019). Reducing 50\% sodium chloride in healthier jerked beef: An efficient design to ensure suitable stability, technological and sensory properties. Meat Science, $152,49-57$.

Vidyasagar, M., Prakash, S., Jayalakshmi, S. K., \& Sreeramulu, K. (2007). Optimization of culture conditions for the production of halothermophilic protease from halophilic bacterium Chromohalobacter sp. TVSP101. World Journal of Microbiology and Biotechnology, 23(5), 655-662.

Williams, S. T. (1989). Bergey's manual of systematic bacteriology. Williams \& Wilkins.

Woese, C. R., Kandler, O., \& Wheelis, M. L. (1990). Towards a natural system of organisms: proposal for the domains Archaea, Bacteria, and Eucarya. Proceedings of the National Academy of Sciences, 87(12), 4576-4579.

Xu, Q., Cui, H. L., \& Meng, F. (2019). Haloprofundus halophilus sp. nov., isolated from the saline soil of Tarim Basin. Antonie van Leeuwenhoek, 112(4), $553-559$. 